Acta vet. scand. $1971,12,523-535$.

From the Department of Food Hygiene, College of Veterinary Medicine, Helsinki, Finland.

\title{
THE EFFECT OF EXPERIMENTAL METHYL MERCURY POISONING ON THE DISTRIBUTION OF ACID PHOSPHATASE DURING AUTOLYSIS IN CAT LIVER
}

\author{
By \\ Timo J. Pekkanen
}

Sporadic outbreaks of an initially unidentified disease of the central nervous system have occurred since 1953 in the city of Minamata in Japan. This disease has been named the "Minamata disease". It was first observed in cats and later in man, and in both species the principal symptoms were similar, being mainly of neurological character. The mortality resulting from this disease approached $40 \%$ (Nomura 1968, Kurland et al. 1960).

On the basis of clinical and pathological observations on human and animal cases of the Minamata disease, of the chemical and histochemical determinations of mercury compounds and also of experimentally induced cases of the disease in animals, there is no doubt now that the Minamata disease is caused by the consumption of food contaminated with organic mercury compounds, particularly methyl mercury (Takeuchi 1968).

Some experiments with inorganic mercury compounds indicate that mercury is accumulated principally intracellularly, in the lysosomes (Norseth 1968; Timm et al. 1966). Histochemical studies have demonstrated an increased acid phosphatase reaction in various organs in connection with intoxication with inorganic mercury compounds (Kosmider 1965, Taylor 1965). As regards organic mercury compounds, the work of Norseth (1967) with methoxyethylmercury also indicates that mercury accumulates to some extent in the lysosomes. 
Alkyl mercury compounds are considered to react rapidly with the sulfhydryl groups of proteins (Kominz 1961, Irukayama et al. 1965, Webb 1966a, Goto \& Fujino 1969). The studies of Hegner (1968) on the functional importance of sulfhydryl groups in the membranes of lysosomal granules of bovine polymorphonuclear leucocytes showed that an organic mercury compound, parachloromercurybenzoate, like other sulfhydryl reagents, increased the permeability of the membranes of isolated lysosomes for enzyme proteins.

The distribution of acid phosphatase between the lysosomal and extralysosomal fraction at the beginning of autolysis (Beafay et al. 1959, Weissmann \& Thomas 1962) and both at the beginning and during the process at $37^{\circ} \mathrm{C}$ (Pekkanen 1970) has been considered to reflect the stability of the lysosomal membrane.

The aim of the present investigation was to study the effect of methyl mercury poisoning on the stability of lysosomal membranes as indicated by the intracellular distribution of acid phosphatase during liver autolysis. For this purpose a group of cats was fed a diet which contained $\mathrm{Hg}^{203}$ labelled methyl mercury. Another group of cats was kept on a similar diet without methyl mercury. At the end of the experimental period, the intracellular distribution of acid phosphatase during autolysis was determined in the livers of all animals. The methyl mercury content of the livers of the test animals was determined, as was also the $\mathrm{pH}$ and the total bacterial count before and after autolysis of the livers.

\section{MATERIAL AND METHODS}

Test animals and their diets

Seven adult male cats with weights varying between 2.35 and $4.30 \mathrm{~kg}$, the "experimental" cats (A, B, C, D, E, F and G), were fed a diet containing methyl mercury once a day. Eight other cats, the "controls" ( H, I, J, K, L, M, N and $O$ ), received the same diet without methyl mercury.

Before starting the experiments all cats were vaccinated against feline panleukopenia with 1 dose of Connaught Feline Panleukopenia Vaccine (Ferring, Malmö, Sweden) and kept before the experiment at least 2 weeks under close observation for possible signs of illness.

All the cats were kept in separate cages during the experi- 
ment, and the condition of each cat was checked once a day during and after a 5 min. period of moderate exercise.

The experiments were carried out over a period of 9 months. All the cats were killed by decapitation, the experimental cats after they had developed heavy neurological symptoms typical of the methyl mercury poisoning (Ushikusa 1965). One hr. before decapitation the cats were given $100 \mathrm{mg} / \mathrm{kg}$ ampicillin natrium (Doctacillin, Astra, Södertälje, Sweden) intramuscularly.

The methyl mercury was fed mixed with liver homogenate, for the preparation of which the liver of a healthy cow was used. Within $1 / 2 \mathrm{hr}$. after the slaughter of the cow the liver was washed with cold tap water, most of the serosa removed and the liver ground twice with a meat grinder. The minced liver was homogenized with a Waring blender (Fischer Scientific Co., New York, USA) and then with an Ultra-Turrax (Janke \& Kunkel KG, Staufen, Germany) homogenizer. The vial with the mixture was kept in ice water during homogenization. After homogenization the homogenate was passed through a cheese-cloth to remove large particles.

For cats A and B, $620.9 \mathrm{~g}$ of the homogenate was diluted with $500 \mathrm{ml}$ of tap water, and $1.063 \mathrm{~g}$ of labelled methyl mercuric hydroxide (Casco, Stockholm, Sweden) in $5 \mathrm{ml}$ of water was added. The mixture was incubated $20 \mathrm{hrs}$. at room temperature under constant shaking and then divided into portions in test tubes corresponding to daily cat doses. The methyl mercury hydroxide was labelled by the addition of $\mathrm{Hg}^{203}$ labelled methyl mercury nitrate (Ab Atomenergi, Studsvik, Sweden). The liver homogenate thus obtained contained $1.03 \mathrm{mg} \mathrm{Hg}$ and $11.9 \mathrm{nCi}$ $\mathrm{Hg}^{203} / \mathrm{g}$ at the beginning of the experiment.

The test tubes containing the homogenate were stored at $-45^{\circ} \mathrm{C}$. The homogenate was removed from the test tubes after immersion in warm water, and then given to the cats in $100 \mathrm{~g}$ portions of ground meat. In addition 2 herrings of about $30 \mathrm{~g}$ were given daily to each cat. Water mixed with powdered milk was available ad libitum to the animals.

The daily dose of the liver homogenate fed to cats A and B was calculated by weighing the contents of 20 test tubes each containing 1 dose of the homogenate. The weight of the daily dose of liver homogenate was $3.64 \pm 0.41 \mathrm{~g}$ (mean $\pm \mathrm{s}$ ) and the daily dose of methyl mercury was accordingly $3.75 \pm 0.42 \mathrm{mg} \mathrm{Hg}$. The liver homogenate and the rest of the diet fed to cats C, D, E, 
F and $G$ was prepared as for cats $A$ and $B$ except that it contained $1.06 \mathrm{mg}$ of $\mathrm{Hg}$ and $0.105 \mathrm{nCi} \mathrm{Hg}^{203} / \mathrm{g}$ at the beginning of the experiment. Each dose of the liver homogenate fed to cats C, D, E, F and G was weighed every day before feeding.

Determination of mercury content in the experimental diet and in the livers of the experimental animals

When liver homogenate is mixed with methyl mercury as described above, practically all the mercury will be protein-bound in the form of methyl mercury (östlund 1969). In experimental animals fed a diet containing protein-bound methyl mercury, the mercury, chiefly in the form of methyl mercury, has been found in various organs, among these the liver (Irukayama et al. 1965).

The total methyl mercury content of the liver homogenate fed to the experimental cats and the total mercury content in the livers of the same animals after their sacrifice were obtained by determination of the content of $\mathrm{Hg}^{203}$. The determination was made with a NaJ scintillation detector (Wallac, Turku, Finland). The mercury determinations were in 4 instances also made by neutron activation analysis (Häsänen 1970).

Determination of the distribution of acid phosphatase during autolysis in the livers of the cats

The distribution of acid phosphatase was expressed as the percentage of unsedimentable activity of acid phosphatase out of the total acid phosphatase activity of the sample. The livers were removed within 2 min. after decapitation, and then minced by pressing through a sieve of steel wire with a hole diameter of $1 \mathrm{~mm}$. The homogenate thus obtained was mixed with a glass rod for $2 \mathrm{~min}$. and, after removal of appropriate samples for mercury determinations, divided into portions of $2 \mathrm{~g}$ and placed in sterile test tubes. All handling of the livers was done at a temperature of $4^{\circ} \mathrm{C}$, and the vials containing the samples were kept in ice. The test tubes with their contents were then incubated in a $37^{\circ} \mathrm{C}$ water bath. The time from the sacrification of the cats until the test tubes with their contents were placed in the water bath varied from 20 to $35 \mathrm{~min}$.

The distribution of acid phosphatase was determined from 3 2-g samples after 0,12 and 24 hrs.' incubation at $37^{\circ} \mathrm{C}$, as previously described (Pekkanen 1970). In addition, the distribution of acid phosphatase was in 2 cases determined also after $6 \mathrm{hrs}$. and in 3 cases after $18 \mathrm{hrs}$. of incubation at the same temperature. If the unsedimentable activity of acid phosphatase in the liver samples was found during autolysis to represent $100 \%$ of the total activity, no further determinations of the distribution were made.

Counting of microorganisms in the livers of the test animals

The total bacterial count of the minced cat livers was taken before the onset and after $24 \mathrm{hrs}$. of incubation of the livers at $37^{\circ} \mathrm{C}$. 
The contents of 1 test tube containing $2 \mathrm{~g}$ of minced liver were diluted with $8 \mathrm{ml}$ of sterile isotonic saline solution and homogenized for 1 min. with an Ultra-Turrax homogenizer. The tube was kept in ice water during homogenization. Two 1-ml samples of the homogenate were each mixed with $15 \mathrm{ml}$ of Plate Count Agar (Oxoid Limited, London, England) in a temperature of $47^{\circ} \mathrm{C}$ on Petri dishes with a diameter of $90 \mathrm{~mm}$. The bacterial count was determined after 48 and 72 hrs.' incubation at $30^{\circ} \mathrm{C}$.

\section{Determination of the $\mathrm{pH}$ during autolysis of the livers}

One test tube containing $2 \mathrm{~g}$ of minced liver was used for $\mathrm{pH}$ determinations before and another after incubation at $37^{\circ} \mathrm{C}$ for $24 \mathrm{hrs}$. The minced liver was homogenized with an Ultra-Turrax homogenizer in $8 \mathrm{ml}$ of distilled water and the $\mathrm{pH}$ determined with a Beckman Zeromatic pH-meter (Beckman instruments, INC., Fullerton, California, USA).

\section{RESULTS}

The data concerning the experimental animals, the feeding of the methyl mercury-containing diet, the results of the methyl mercury determinations in the liver homogenate fed to the experimental animals and the results of mercury determinations in the livers of the same animals after their sacrifice are given in Table 1.

The total amount of methyl mercury fed to the cats, expressed in terms of $\mathrm{mg}$ of inorganic mercury per $\mathrm{kg}$ body weight, varied between 29.14 and $40.12 \mathrm{mg}$, the mean being $34.94 \pm 4.46 \mathrm{mg}$. The mercury content in the livers of the cats fed with the liver homogenate containing methyl mercury varied between 102.5 and $128.7 \mathrm{mg}$ per $\mathrm{kg}$ wet weight of the liver, the mean being $113.6 \pm 4.4 \mathrm{mg} / \mathrm{kg}$.

The effect of methyl mercury poisoning on the distribution of acid phosphatase during and before autolysis at $37^{\circ} \mathrm{C}$

The curves A, B, C, D, E, F and $G$ in Fig. 1 show the distribution of acid phosphatase in the livers of the cats fed the methyl mercury diet, and the curves $\mathrm{H}, \mathrm{I}, \mathrm{J}, \mathrm{K}, \mathrm{L}, \mathrm{M}, \mathrm{N}$ and $\mathrm{O}$ the distribution of acid phosphatase in the livers of the cats kept as controls without methyl mercury in their diet. The share of the unsedimentable activity of acid phosphatase in the total acid phosphatase activity of the samples before incubation at $37^{\circ} \mathrm{C}$ varied in the livers of the experimental cats from 16 to $31 \%$, 
T a b l e 1. Experimentally induced methyl mercury poisoning in cat ${ }^{\star}$ ). The cats were fed an experimental diet, which contained methyl mercury hydroxide in liver homogenate.

\begin{tabular}{|c|c|c|c|c|c|c|c|c|}
\hline \multirow[b]{3}{*}{ Cat } & \multirow{3}{*}{$\begin{array}{l}\text { Weight } \\
\text { of the cat } \\
\text { at the } \\
\text { beginning } \\
\text { of the } \\
\text { experi- } \\
\text { ment, } \\
\text { kg }\end{array}$} & \multicolumn{6}{|c|}{ Feeding of methyl mercury } & \multirow{3}{*}{$\begin{array}{l}\text { Mercury } \\
\text { content } \\
\text { in liver, } \\
\text { mg per kg } \\
\text { of liver } \\
\text { weight }\end{array}$} \\
\hline & & \multirow{2}{*}{$\begin{array}{c}\text { number of } \\
\text { days of } \\
\text { feeding of } \\
\text { the experi- } \\
\text { mental diet } \\
\text { until onset } \\
\text { of first } \\
\text { neurologic- } \\
\text { al symp- } \\
\text { toms }\end{array}$} & \multirow{2}{*}{$\begin{array}{c}\text { feeding } \\
\text { period } \\
\text { of the } \\
\text { experi- } \\
\text { mental } \\
\text { diet, } \\
\text { days }\end{array}$} & \multicolumn{2}{|c|}{$\begin{array}{l}\text { methyl mercury } \\
\text { content of the } \\
\text { liver homogenate, } \\
\text { mg per } g\end{array}$} & \multirow{2}{*}{$\begin{array}{c}\text { average } \\
\text { daily } \\
\text { feeding } \\
\text { of methyl } \\
\text { mercury } \\
\text { per cat, } \\
\text { mg } \\
(\text { mean } \pm s)\end{array}$} & \multirow{2}{*}{$\begin{array}{c}\text { total } \\
\text { feeding } \\
\text { of methyl } \\
\text { mercury, } \\
\text { mg per kg } \\
\text { of body } \\
\text { weight }\end{array}$} & \\
\hline & & & & $\begin{array}{l}\text { determin- } \\
\text { ed with } \\
\text { NaJ } \\
\text { scintil- } \\
\text { lation } \\
\text { detector }\end{array}$ & $\begin{array}{l}\text { determin- } \\
\text { ed by } \\
\text { neutron } \\
\text { activa- } \\
\text { tion } \\
\text { analysis }\end{array}$ & & & \\
\hline A & 3.89 & 30 & 34 & 1.03 & 1.10 & $3.75 \pm 0.42$ & 32.75 & $\left.102.5^{\star \star}\right)$ \\
\hline B & 4.13 & 40 & 42 & 1.03 & 1.10 & $3.75 \pm 0.42$ & 38.14 & $\left.104.6^{\star \star}\right)$ \\
\hline C & 2.35 & 16 & 17 & 1.06 & - & $4.33 \pm 0.13$ & 31.33 & 117.0 \\
\hline D & 3.40 & 26 & 32 & 1.06 & - & $4.26 \pm 0.15$ & 40.12 & 115.2 \\
\hline $\mathbf{E}$ & 2.85 & 21 & 22 & 1.06 & - & $4.27 \pm 0.16$ & 32.99 & 117.7 \\
\hline $\mathbf{F}$ & 3.60 & 32 & 34 & 1.06 & - & $4.25 \pm 0.23$ & 40.12 & 128.7 \\
\hline G & 4.30 & 25 & 29 & 1.06 & - & $4.26 \pm 0.18$ & 29.14 & 110.0 \\
\hline
\end{tabular}

*) the methyl mercury contents are expressed as metallic mercury on wet weight basis.

${ }^{\star *}$ ) determined by neutron activation analysis.

the mean being $25.1 \pm 5.1 \%$, and in the livers of the control cats from 14 to $26 \%$ with a mean of $20.7 \pm 4.1 \%$. The difference between the means is highly significant $\left.(P<0.001)^{*}\right)$.

When the liver samples had been incubated at $37^{\circ} \mathrm{C}$ for 12 hrs., the unsedimentable acid phosphatase activity in the livers of the experimental cats varied from 65 to $100 \%$ of the total acid phosphatase activity of the corresponding liver samples. The mean was found to be $82.7 \pm 16.4 \%$. In the livers of the control cats the corresponding share of the activity of unsedimentable acid phosphatase varied between 34 and $54 \%$ of the total acid phosphatase activity. The mean was found to be $45.6 \pm 7.4 \%$. The difference of the mean percentages is again highly significant $(P<0.001)$. In the liver samples of the experimental cats $A, B$ and $D$ the unsedimentable acitivity of acid phosphatase was $100 \%$ of the total acid phosphatase activity of the corresponding liver samples. In the experimental cats $\mathrm{C}, \mathrm{E}$ and $\mathrm{F}$ the distri-

*) The statistical calculations were made using the Student's t-test. 


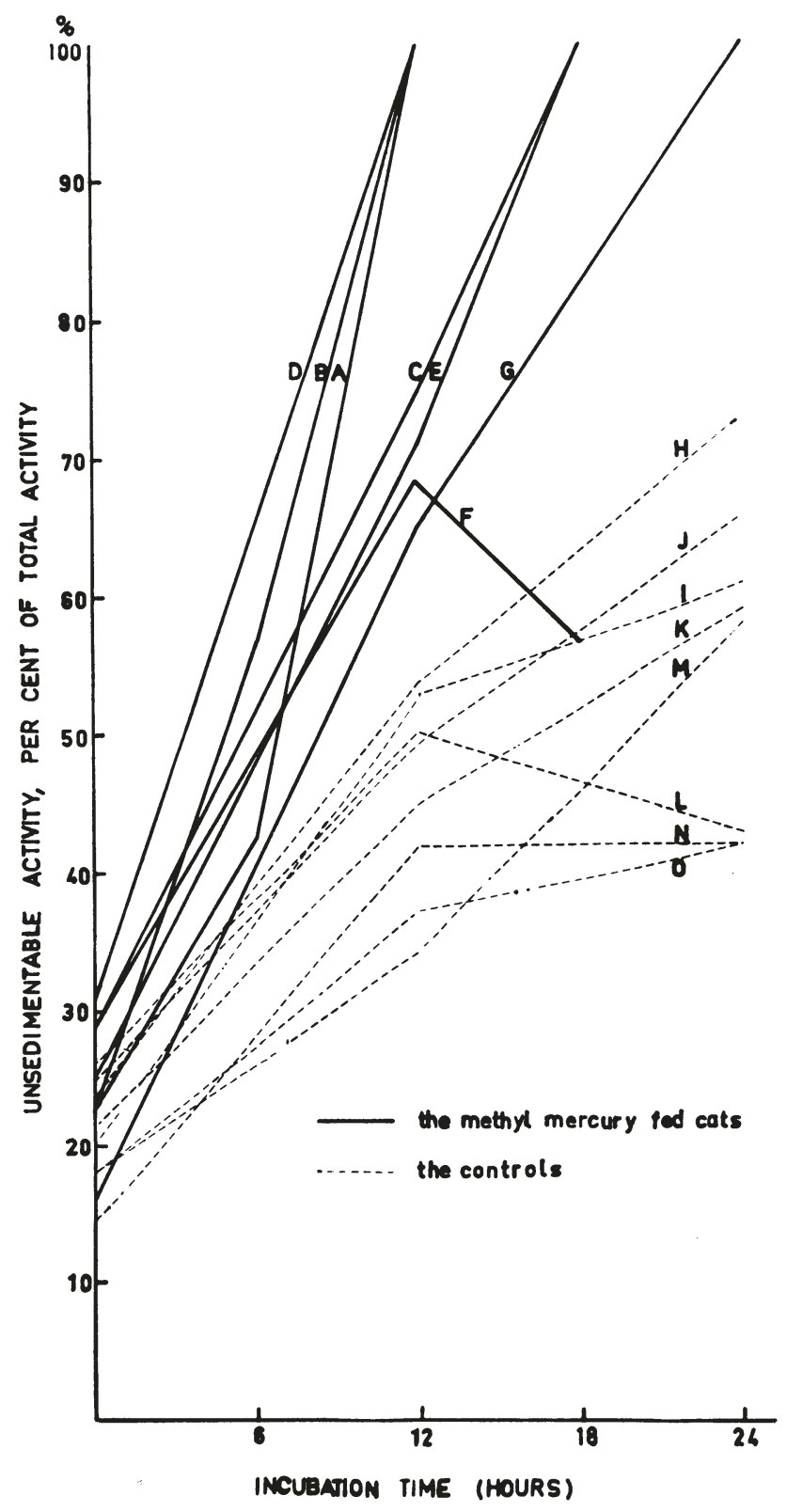

F igure 1. Distribution of acid phosphatase during autolysis in cat liver. 
bution of acid phosphatase in their livers was additionally determined again after 18 hrs.' incubation. The unsedimentable activity of acid phosphatase in the livers of cats $C$ and $E$ represented $100 \%$ of the total activity of acid phosphatase and in the liver of cat $\mathrm{F} 57 \%$.

Cat $G$ was the only one of the experimental animals in which the distribution of acid phosphatase was determined after 24 hrs.' incubation. The share of unsedimentable acid phosphatase activity of the total activity of acid phosphatase in the liver of the cat $\mathrm{G}$ was then $100 \%$ and in the control cats from 42 to $73 \%$, the mean being $57.4 \pm 11.4 \%$.

Results of the bacteriological examinations and the pH determinations of the cat livers

The total bacterial count was zero with the used method in the liver samples of all cats both before and after a $24 \mathrm{hr}$. incubation at $37^{\circ} \mathrm{C}$.

In the livers of the experimental cats the $\mathrm{pH}$ varied between 6.70 and 6.90 before incubation, the mean being $6.84 \pm 0.08$, and in the control cats H, I, J, K, L, M, N and $O$ between 6.40 and 6.70, the mean being $6.50 \pm 0.09$. After the livers had been incubated $24 \mathrm{hrs}$. at $37^{\circ} \mathrm{C}$ the $\mathrm{pH}$ varied in the livers of cats $\mathrm{A}, \mathrm{B}, \mathrm{C}, \mathrm{D}, \mathrm{E}, \mathrm{F}$ and $G$ from 6.10 to 6.20 , the mean being $6.12 \pm 0.05$, and in the livers of cats $\mathrm{H}, \mathrm{I}, \mathrm{J}, \mathrm{K}, \mathrm{L}, \mathrm{M}, \mathrm{N}$ and $\mathrm{O}$ from 5.40 to 6.00 , the mean being $5.84 \pm 0.19$. The mean $\mathrm{pH}$ of the livers of the experimental cats was significantly higher $(\mathrm{P}<0.001)$ than the mean $\mathrm{pH}$ of the livers of the control cats, both before and after a $24 \mathrm{hr}$. incubation at $37^{\circ} \mathrm{C}$.

\section{DISCUSSION}

Because the weight of the cats fed the methyl mercury diet varied (Table 1) and the daily dose of methyl mercury fed to each of the cats was about $4 \mathrm{mg}$, expressed in terms of mercury, the time which elapsed from the beginning of the methyl mercury diet until the occurrence of the first detectable neurological symptoms, the unsteadiness of gait in the rear legs, varied. Although the neurological symptoms were first observed in the leanest of the cats, cats $C$ and $E$, both the differences in the total amount of methyl mercury consumed (expressed as $\mathrm{mg}$ of mercury per $\mathrm{kg}$ of body weight) and the differences in the mercury contents in the livers of the experimental cats indicate 
individual variations in sensitivity to methyl mercury in the experimental animals (Ushikusa 1965). In fact, comparatively large individual variations in the latency time have been considered typical signs of alkyl mercury poisoning in cats (Irukayama et al. 1965) and man (Swensson d Ulfvarson 1963).

Before the incubation at $37^{\circ} \mathrm{C}$, the mean share of the unsedimentable activity of acid phosphatase out of the total activity of the livers of the 7 experiniental cats was $25.1 \pm 5.1 \%$, which is significantly $(\mathrm{P}<0.001)$ greater than the corresponding mean share, $20.7 \pm 4.1 \%$, of the livers of the 8 controls. This possibly indicates either an intravital release of acid phosphatase from the lysosomes in the liver cells or a decreased resistance of the lysosome membranes of the liver cells of the methyl mercuryexposed animals to disintegrating forces during homogenization. This phenomenon has been observed on liver lysosomes in connection with exposure to other toxic agents (Weissmann $\&$ Thomas 1962, Dingle 1963), among them inorganic mercury compounds (Norseth 1968). Because the percentage of the unsedimentable activity of acid phosphatase increases during incubation at $37^{\circ} \mathrm{C}$ more rapidly in the livers of the methyl mercury-fed cats than in the control cats (Fig. 1), it is also possible that the observed differences before incubation may be due solely to this, and consequently represent a rather rapid post-mortal phenomenon. Although the possibility of an intravital release of acid phosphatase seems to correspond to the theory of the functions of lysosomes (de Duve 1963), no final conclusions can be drawn. Fig. 1 shows that the share of unsedimentable activity reaches $100 \%$ of the total activity of acid phosphatase in the livers of the experimental cats after 12 to $24 \mathrm{hrs}$. of incubation at $37^{\circ} \mathrm{C}$, except in the liver of cat $\mathrm{F}$. In the control animals, the corresponding proportion was in no case higher than $73 \%$.

It can be concluded that the differences observed during liver autolysis in the share of unsedimentable acid phosphatase activity out of the total between methyl mercury-exposed and control animals (Fig. 1) are due either to a difference between the respective animal groups in the resistance of the liver lysosome membranes to homogenization, or to a difference in the rate of release of lysosome-bound acid phosphatase from lysosome to cytoplasm during autolysis.

Hegner (1968) has shown the membranes of isolated lysosomes to be sensitive to mercury sulfhydryl-reagents. He did not, 
however, study the effects of methyl mercury. The reagents used caused an increased release of lysosomal enzymes, among them acid phosphatase. The methyl mercury which during poisoning accumulates principally in the liver and is known to react with sulfhydryl groups (Weissmann \& Thomas, Webb 1966b) is thus a possible cause of the difference observed between the distribution pattern of acid phosphatase in the methyl mercury-fed and the control animals. The mechanism of action of the sulfhydryl reagents in this respect is not known, but possibly the labilization which has been observed both in cellular and subcellular membranes (Fong et al. 1959, Webb 1966c) is related to the activation (Webb 1966d) or inhibition (Neubert 1963, Munder et al. 1965, Netter 1966) of the enzymes of the cell by these reagents.

The difference of the mean $\mathrm{pH}$-values between the livers of the experimental and the control animals, and the high mercury concentrations found in the livers, possibly indicate an inhibition of the Embden-Meyerhof pathway enzymes in the livers of the experimental cats by methyl mercury during autolysis (Webb 1966d).

A decrease of the share of the unsedimentable acid phosphatase out of the total, as observed in cat $F$ after 12 hrs.' incubation, has not previously been observed. Possible explanations of this observation include a reformation of lysosomal membranes during autolysis, a binding of unsedimentable activity of acid phosphatase to cell debris or a polymerization of enzyme molecules to a size which is sedimentable by the used ultracentrifuge treatment. Even a mercury-induced stability of the lysosomes against homogenization or simply an experimental error cannot be excluded in this case.

\section{REFERENCES}

Beafay, H., E. von Campenhaut \& C. de Duve: Tissue fractionation studies. II. Influence of various hepatoxic treatments on the state of some bound enzymes in rat liver. Biochem. J. 1959, 73, $617-623$.

Dingle, $J$.T.: Action of vitamin A on the stability of lysosomes in vivo and in vitro. In Lysosomes. Ciba foundation symposium, ed. V. S. de Reuck \& M. P. Cameron. J. \& A. Churchill, Ltd., London $1963,384-398$.

de Duve, C.: The Lysosome concept. In Lysosomes. Ciba foundation symposium, ed. V. S. de Reuck \& M. P. Cameron. J. \& A. Churchill, Ltd., London 1963, $1-35$. 
Fong, C. T. O., J. L. Schwartz, E. A. Popence, L. Silver \& M. A. Schoessler: On the molecular bounding of lysine vasopressin at its venal receptor site. J. Amer. chem. Soc. 1959, 81, 2592.

Goto, T. \& M. Fujino: Counteraction of sulfhydryls $(\mathrm{SH})$ in rats against mercury. I. Influence of methionine on the growth of rats given a diet containing mercury pestisides, and $\mathrm{SH}$ in liver. J. Jap. Soc. Fd Nutr. 1969, 22, 73-77.

Hegner, D.: Funktionelle Bedeutung von SH-Gruppen in Membranen von Lysosomalen Granula aus polymorphkernigen Rinderleucocyten. (Functional importance of sulfhydryl groups in membranes of lysosomal granules of bovine polymorphonuclear leucocytes). Naunyn-Schmiedeberg's Arch. exp. Path. Pharmak. 1968, 261, 239-251.

Häsänen, E.: Determination of mercury in biological material by neutron activation analysis. Acta chem. fenn. 1970, 43A, 251254.

Irukayama, K., F. Kai, T. Kondo, S. Ushikusa, M. Fujiki \& S. Tajima: Toxicity and metabolism of methyl mercury compounds in animals - especially in relation to Minamata disease. Jap. J. Hyg. 1965, 20, 11-21.

Kominz, D. R.: Molecular changes in myosin caused by methyl-mercuric hydroxide. Biochim. biophys. Acta (Amst.) 1961, 51, $456-463$.

Kośmider, St.: Untersuchungen über den toxischen Wirkungsmechanismus des metallischen Quecksilbers. (Studies on the toxic mechanism of action of the metallic mercury). Arch. Gewerbepath. Gewerbehyg. $1965,21,282-314$.

Kurland, L. T., S. N. Faro \& H. Siedler: Minamata disease. The outbreak of a neurological disorder in Minimata Japan and its relationship to the ingestion of seafood contaminated by mercuric compounds. Wld Neurol. 1960, 1, 370—391.

Munder, P. G., E. Ferber \& H. Fischer: Untersuchungen über die Abhängigkeit der cytolytischen Wirkung des Lysolecithins von Membranenzymen. (Studies on the dependence between the cytolytic effect of the lysolecithins and the membrane enzymes). Z. Naturforsch. 1965, 20b, 1048.

Netter, K. J.: Sulfhydrylgruppen in Lebermikrosomen. (The sulfhydryl groups of the liver microsomes). Naunyn-Schmiedeberg's Arch. exp. Path. Pharmak. 1966, 253, 76.

Neubert, D.: Einfluss von Pharmaka auf energieliefernde Reaktionen des Stoffwechsels. (The effect of drugs on the energy producing reactions of the metabolism). Naunyn-Schmiedeberg's Arch. exp. Path. Pharmak. 1963, 246, 101-132.

Nomura, S.: Epidemiology of Minamata disease. In Minamata Disease. Study group of Minamata disease, ed. M. Kutsuna. Kumamoto University, Japan 1968, 5-36.

Norseth, T.: The intracellular distribution of mercury in rat liver after methoxyethylmercury intoxication. Biochem. Pharmacol. $1967,16,1645-1654$. 
Norseth, T.: The intracellular distribution of mercury in rat liver after at single injection of mercuric chloride. Biochem. Pharmacol. 1968, 17, 581-593.

Pekkanen, T. J.: Distribution of acid phosphatase during autolysis in bovine liver. Acta vet. scand. 1970, 11, 283-294.

Swensson, $A$. \& U. Ulfvarson: Toxicology of organic mercury compounds used as fungicides. Occup. Hith Rev. 1963, 15, 5-11.

Takeuchi, T.: Experiments with organic mercury, particularly with methyl mercury compounds; Similarities between experimental poisoning and Minamata Disease. In Minamata Disease. Study group of Minamata disease, ed. M. Kutsuna. Kumamoto University, Japan 1968, 229-252.

Taylor, N. S.: Histochemical studies of nephrotoxicity with sublethal dose of mercury in rats. Amer. J. Path. 1965, 46, 1-14.

Timm, F., Ch. Naundorf \& M. Kraft: Zur Histochemie und Genese der chronischen Quecksilbervergiftung. (On the histochemistry and development of the chronic mercury poisoning). Arch. Gewerbepath. Gewerbehyg. 1966, 22, 236-245.

Ushikusa, S.: Supplementary experiments on the toxicity of methylmercuric chloride in cats administered per os. Kumamoto med. J. 1965, 39, 33-39.

Webb, J. L.: Mercurials. Chapter 7. In Enzyme and Metabolic Inhibitors. Acad. Press. New York and London 1966, Vol. II, a $746-768$; b 892-916; c 815-820; d 830-859, 874.

Weissmann, G. \& L. Thomas: Studies on lysosomes. I. The effects of endotoxin, endotoxin tolerance and cortisone on the release of acid hydrolases from a granular fraction of rabbit liver. J. exp. Med. 1962, 116, 433-450.

östlund, $K$. : Extraction of mercury compounds from organic material. In Studies on the Metabolism of Methyl Mercury and Dimethyl Mercury in Mice. Acta pharmacol. (Kbh.) 1969, 27, Suppl. 1, 38.

\section{SUMMARY}

Seven healthy male cats weighing between 2.35 and $4.30 \mathrm{~kg}$ were daily fed a diet which contained $\mathrm{Hg}^{203}$ labelled methyl mercury hydroxide in liver homogenate. Eight additional cats were kept as controls on a similar diet without methyl mercury hydroxide. The daily amount of methyl mercury hydroxide fed to the cats, expressed as inorganic mercury, varied between 3.75 and $4.33 \mathrm{mg}$ per cat. When the animals had developed neurological symptoms typical of methyl mercury poisoning, they were decapitated and their livers removed for the determination of the mercury content, the distribution of acid phosphatase during autolysis at $37^{\circ} \mathrm{C}$, the $\mathrm{pH}$ and the total bacterial count before and after a $24 \mathrm{hr}$. period of autolysis. Similar determinations except for the mercury were made from the livers of the control animals. The total amount of methyl mercury hydroxide fed to the cats varied between 29.14 and $40.12 \mathrm{mg} \mathrm{Hg}^{++}$per $\mathrm{kg}$ of body weight, and the mercury content in their livers between 102.5 and $128.7 \mathrm{mg} \mathrm{Hg}^{++}$per $\mathrm{kg}$ of liver wet weight. 
The share of unsedimentable activity of acid phosphatase out of the total immediately after decapitation was found to be significantly $(P<0.001)$ greater in the livers of the methyl mercury-fed cats than in the livers of the control animals. After 12 to $24 \mathrm{hrs}$. of autolysis at $37^{\circ} \mathrm{C}$ the unsedimentable activity accounted for $100 \%$ of the total acid phosphatase activity in the livers of 6 of the 7 methyl mercuryfed animals, while in the livers of the controls the corresponding percentages varied after $24 \mathrm{hrs}$. of incubation between 42 and 73, the mean being $57.4 \pm 11.4 \%$. The mean $\mathrm{pH}$ of the livers of the methyl mercury fed animals was found to be significantly higher before $(\mathrm{P}<0.001)$ and after $(\mathrm{P}<0.001)$ a $24 \mathrm{hr}$. incubation at $37^{\circ} \mathrm{C}$ than the corresponding mean $\mathrm{pH}$ values of the control animals.

Because of the injection of antibiotics given to the cats before sacrifice the total bacterial count of the livers, which was checked before and after a $24 \mathrm{hr}$. incubation at $37^{\circ} \mathrm{C}$, was found to be zero.

\section{SAMMANFATTNING \\ Inverkan av metylkvicksilverförgiftning på fördelning av surt fosfatas under autolys $i$ kattlever.}

Sju hankatter, vars vikter varierade mellan 2,35 och $4,30 \mathrm{~kg}$ utfodrades dagligen med ett foder som innehöll $\mathrm{Hg}^{203}$ märkt metylkvicksilverhydroksid blandat med leverhomogenat. Åtta katter, „kontrollerna“, fick samma foder utan metylkvicksilver. Den dagliga givan av metylkvicksilver uttryckt som $\mathrm{Hg}^{++}$per katt varierade mellan 3,75 och 4,33 mg. När djuren visade grava för metylkvicksilverförgiftning typiska neurologiska symptom avlivades de och deras levrar tillvaratogs för kvicksilverbestämning, för bestämning av $\mathrm{pH}$ och det totala bakterietalet före och efter en 24 timmars inkubation vid $37^{\circ} \mathrm{C}$. Samma bestämningar med undantag av kvicksilveranalys utfördes på kontrollkatternas levrar. Totalmängden av metylkvicksilver som utfodrades till katterna varierade mellan 29,14 och $40,12 \mathrm{mg} \mathrm{Hg}^{++}$per $\mathrm{kg}$ kroppsvikt och det motsvarande kvicksilverinnehållet i levrarna mellan 102,5 och $128,7 \mathrm{mg} \mathrm{Hg}^{++}$per $\mathrm{kg}$ lever.

Omedelbart efter avlivandet av katterna var det sytoplasmatiska sura fosfatasets andel av det totala signifikant $(P<0,001)$ större i de med metylkvicksilver utfodrade katternas levrar jämnfört med kontrollernas levrar. Efter 12 till 24 timmars inkubation vid $37^{\circ} \mathrm{C}$ var den sytoplasmatiska aktivitetens andel av den totala aktiviteten $100 \%$ i sex av de sju med metylkvicksilver utfodrade katterna. Motsvarande andel var hos kontrollerna efter 24 timmars inkubation $57 \pm 11,4 \%$. Levrarnas genomsnittliga $\mathrm{pH}$-värde var signifikant $(\mathrm{P}<0,001)$ större hos de med metylkvicksilver utfodrade katterna än hos kontrollerna både före och efter en 24 timmars inkubation vid $37^{\circ} \mathrm{C}$.

På grund av antibiotikum injektion omedelbart före avlivandet var det totala bakterietalet noll med den användade metoden både före och efter en 24 timmars inkubation vid $37^{\circ} \mathrm{C}$. 